\title{
Volunteer Fire Fighter Killed Rescuing Injured Construction Worker When Struck by Collapsing Cell Phone Tower - West Virginia
}

\section{Executive Summary}

On February 1, 2014, a 28-year-old male volunteer fire fighter died after being struck by a collapsing cell phone tower. The fire fighter was rescuing an injured construction worker who had been hurt during the collapse of a separate cell phone tower located on the same site. He and three other fire fighters were dragging the injured maintenance worker out of the danger zone of the first collapsed tower when a second tower collapsed and struck him as he attempted to run away. He was transported to a local hospital where he was pronounced dead. The initial tower collapse occurred during scheduled maintenance to reinforce the tower.

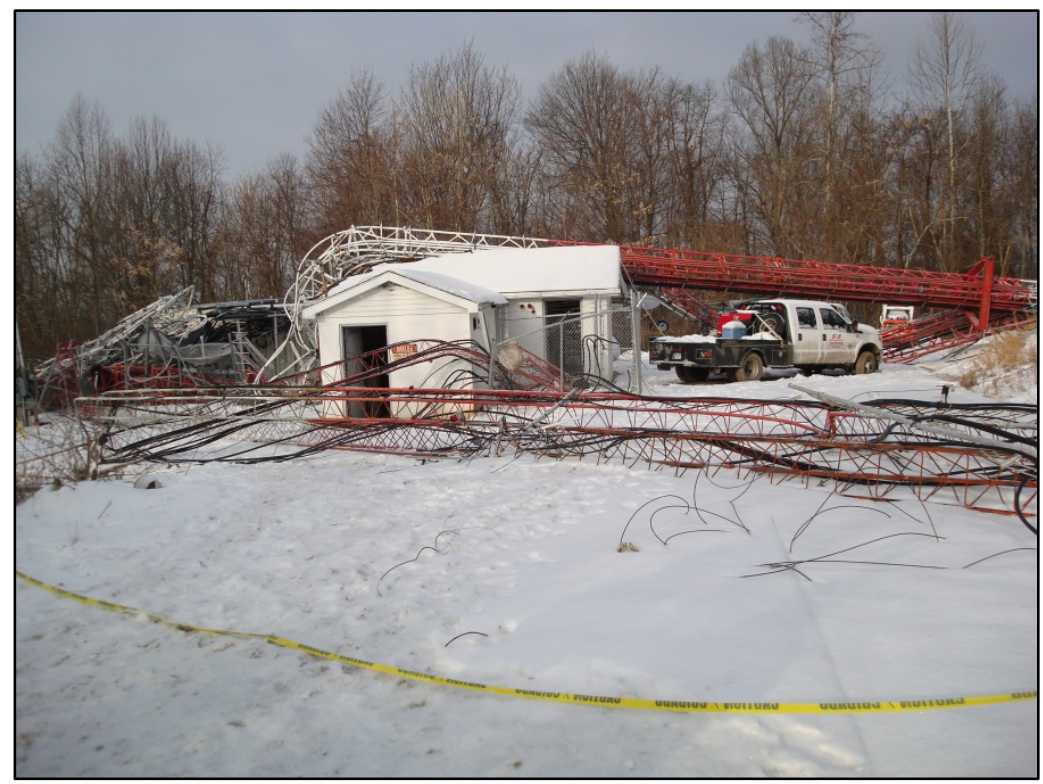

Site of collapsed cell phone towers. (NIOSH photo)

\section{Contributing Factors}

- Sequential collapses of two cell phone towers

- Ineffective Incident Command

- Lack of situational awareness

- Lack of training for the specific incident response

- Lack of an Incident Safety Officer.

\section{Key Recommendations}

- Fire departments should develop, implement and enforce an occupational safety and health program in accordance with NFPA 1500 Standard for a Fire Department Occupational Safety and Health Program

- Fire departments should ensure that the incident commander conducts an initial size-up and risk assessment of the incident scene before beginning operations, establishes a stationary 


\section{Volunteer Fire Fighter Killed Rescuing Injured Construction Worker When Struck by Collapsing Cell Phone Tower - West Virginia}

command post, maintains the role of director of the incident scene and does not become involved in operations

- Fire departments should ensure that fire fighters are trained in situational awareness, personal safety, and accountability

- Fire departments should develop pre-incident plans for deployment to technical rescue incidents and conduct a risk benefit analysis for the deployment

- Fire departments should ensure that a separate Incident Safety Officer, independent from the Incident Commander, is appointed at technical rescue incidents

- Fire departments, especially volunteer departments, should consider limiting their special operations functions to those that they are properly trained and equipped for.

The National Institute for Occupational Safety and Health (NIOSH), an institute within the Centers for Disease Control and Prevention (CDC), is the federal agency responsible for conducting research and making recommendations for the prevention of work-related injury and illness. In 1998, Congress appropriated funds to NIOSH to conduct a fire fighter initiative that resulted in the NIOSH "Fire Fighter Fatality Investigation and Prevention Program" which examines line-of-duty-deaths or on duty deaths of fire fighters to assist fire departments, fire fighters, the fire service and others to prevent similar fire fighter deaths in the future. The agency does not enforce compliance with State or Federal occupational safety and health standards and does not determine fault or assign blame. Participation of fire departments and individuals in NIOSH investigations is voluntary. Under its program, NIOSH investigators interview persons with knowledge of the incident who agree to be interviewed and review available records to develop a description of the conditions and circumstances leading to the death(s). Interviewees are not asked to sign swom statements and interviews are not recorded. The agency's reports do not name the victim, the fire department or those interviewed. The NIOSH report's summary of the conditions and circumstances surrounding the fatality is intended to provide context to the agency's recommendations and is not intended to be definitive for purposes of determining any claim or benefit. 


\section{Death in the line of duty...}

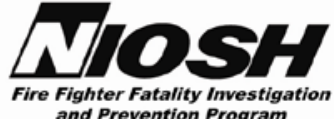

and Prevention Program

A summary of a NIOSH fire fighter fatality investigation

January 20, 2015

\section{Volunteer Fire Fighter Killed Rescuing Injured Construction Worker When Struck by Collapsing Cell Phone Tower - West Virginia}

\section{Introduction}

On February 1, 2014, a 28-year-old male volunteer fire fighter died after being struck by a collapsing cell phone tower. On February 4, 2014, the U.S. Fire Administration notified the National Institute for Occupational Safety and Health (NIOSH) of this incident. On February 7, 2014 a safety and occupational health specialist and a safety engineer with the NIOSH Fire Fighter Fatality Investigation and Prevention Program traveled to the incident site and met with representatives of the cell phone tower owner and the U.S. Department of Labor, Occupational Safety and Health Administration (OSHA). The West Virginia State OSHA representative was also present at this meeting.

From February 13 through February 25, 2014, the safety and occupational health specialist and a general engineer from the NIOSH Fire Fighter Fatality Investigation and Prevention Program traveled to the area to conduct interviews and meetings. The NIOSH investigators met with the Fire Chiefs and fire fighters from the two volunteer fire departments who responded on the initial dispatch, the Fire Chief and fire fighters from the nearby career department who also responded, representatives from the West Virginia State Police, the county dispatch center, and the West Virginia Department of Natural Resources (DNR) officer who responded to the incident scene on the day of the cell tower collapse. The NIOSH representatives interviewed the fire fighters and officers involved in the incident.

\section{Fire Department}

The volunteer fire fighter department, Company 7, where the deceased fire fighter served, has 1 station with 35 uniformed members which serve a population of approximately 9,000 within an area of about 88 square miles. The department responds to more than 600 calls per year ranging from fires, vehicle crashes, medical emergencies, technical rescues, and public service calls. The department operates two engines; one heavy rescue vehicle; a tanker; two utility trucks; a brush unit; an off-road utility vehicle for off-road rescue, fire suppression, and recovery; and a boat.

The volunteer department, Company 13, that was dispatched first due and where the initial incident commander served, had 1 station with 4 uniformed members, serving a population of approximately 3,500 within an area of about 35 square miles.

Currently, 15 volunteer fire departments operate as separate entities within the county.

\section{Training and Experience}

The West Virginia State Fire Commission mandates that career or volunteer fire fighters in the State of West Virginia must be certified to NFPA 1001, Standard on Fire Fighter Professional Qualifications, Fire Fighter I. Fire fighters also have to be certified in Hazardous Materials Awareness, Hazardous 


\section{Volunteer Fire Fighter Killed Rescuing Injured Construction Worker When Struck by Collapsing Cell Phone Tower - West Virginia}

Materials Operations, CPR, and Basic First Aid (120 hours). The state also mandates that all fire officers be certified to NFPA 1021, Fire Officer Professional Qualifications, Fire Officer I and all fire chiefs and other chief officers must be certified to NFPA 1021, Fire Officer II.

\section{Incident Commander}

The initial incident commander (from Company 13) had more than 37 years of experience and over 10 years as a chief officer. The IC's department and the IC did not have any training records to provide to NIOSH during the investigation and were not able to document compliance with the state training requirements. The department did not provide the NIOSH investigators with documentation of any standard operating procedures, training requirements, training records, or department requirements to become a fire fighter.

\section{Fire Fighter}

The deceased fire fighter had more than 15 years of experience and had received training on topics including emergency medical technician; fire fighter I and fire fighter II; fire officer I; emergency vehicle operations; hazardous materials awareness and operations; principles of extrication; rope rescue awareness and swift water rescue awareness. He also received training in a number of National Incident Management System (NIMS) training including ICS-100 Introduction to incident command; ICS-200 ICS for single resources and initial action incidents; IS-362-Multi-Hazard Emergency Planning for Schools; NIMS 400 Advanced Incident Command System; IS-700-Introduction to NIMS; IS-701.a NIMS Multiagency Coordination System (MACS); IS-702.a NIMS Public Information Systems; IS-703.a NIMS Resource Management; IS-704 NIMS Communications and Information Management; and IS-800.b National Response Framework. He was certified by the West Virginia State Fire Commission to the Fire Fighter I level in 2002 and the Fire Fighter II level in 2005. He was also certified to the Fire Officer I level.

\section{Site and Tower Description}

The site covered more than 2.5 acres on top of a hill that was located within the jurisdiction of Company 13, the first due fire department. There were two cell phone towers and three structures that housed electrical components and a generator to support the operation of the cell phone towers. Access to the towers was up a muddy, partially graveled road requiring use of a four-wheel drive vehicle (Photo 1). The owner of the site had contracted a company to improve the site access road to accommodate tower maintenance work.

Tower 1 was 343 feet tall. It consisted of three 41" sides and three round legs that were fastened together with diagonal braces forming the shape of a triangle. The tower was secured with guy wires connecting it to ground anchoring points inserted into concrete slabs (see Diagram). The guy wires were attached to Tower 1 at elevations of 80 feet, 160 feet, 240 feet, and 320 feet. Tower 1 was the first tower to collapse.

Tower 2 consisted of three sides approximately 16” wide and three round legs fastened together with a continuous 3/8” solid bar welded to the legs in a diagonal pattern along its entire 312-foot length. Tower 2 was also secured with guy wires attached to it and to ground anchoring points inserted into 


\section{Volunteer Fire Fighter Killed Rescuing Injured Construction Worker When Struck by Collapsing Cell Phone Tower - West Virginia}

concrete slabs (see Diagram). During the collapse of Tower 1, the top portion of Tower 2 also collapsed most likely from some of the guy wires on Tower 1 contacting the top of Tower 2 and pulling it to the ground. There was approximately 180 feet of Tower 2 still standing when the first due companies arrived.

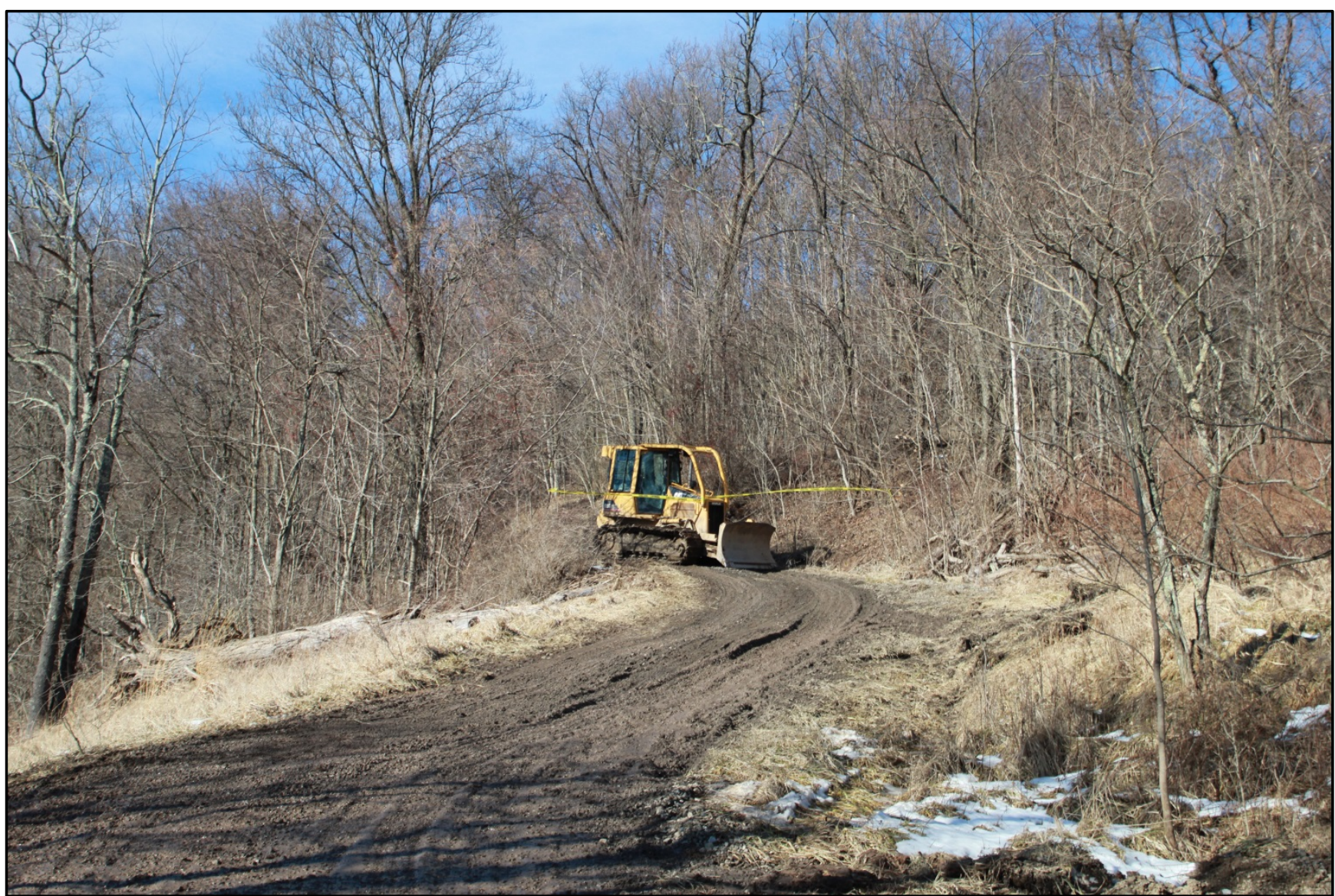

Photo 1. Road conditions up hill to cell tower collapse site. (Photo courtesy of WV State Police.) 
Volunteer Fire Fighter Killed Rescuing Injured Construction Worker When Struck by Collapsing Cell Phone Tower - West Virginia

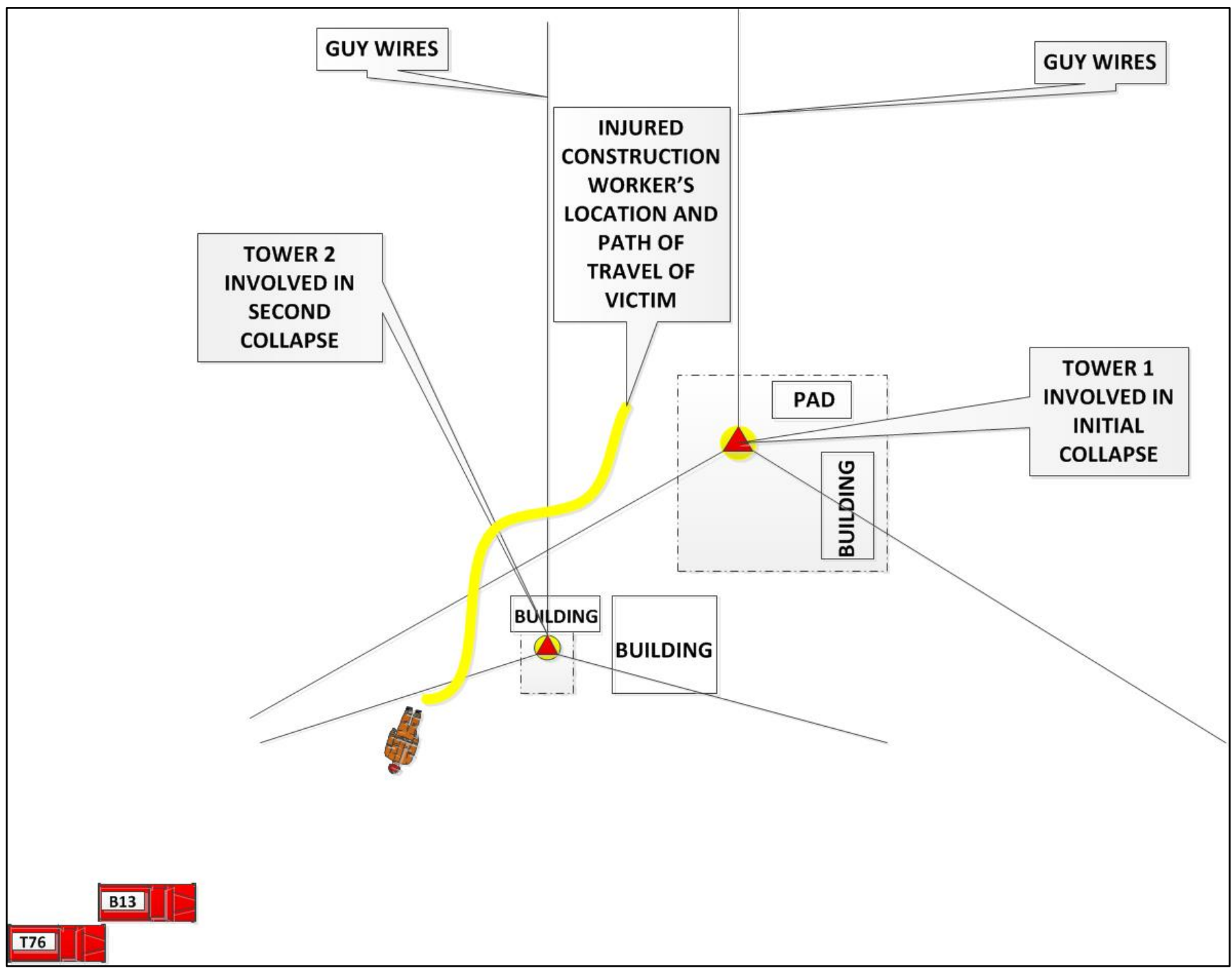

Diagram. Site layout.

\section{Cell Tower Maintenance}

Both towers had been inspected in May 2013 and scheduled for maintenance. A five-person crew was on-site February 1, 2014 to conduct the maintenance. Four of the maintenance workers ascended Tower 1 and started removing damaged diagonal bracing members prior to replacing them with new, larger members and the associated hardware. The other maintenance worker stayed on the ground to fabricate the new members and assist in raising them to the maintenance workers on the tower. 


\section{Volunteer Fire Fighter Killed Rescuing Injured Construction Worker When Struck by Collapsing Cell Phone Tower - West Virginia}

Three of the maintenance workers had ascended to a height of approximately 70 feet. The other maintenance worker ascended to approximately 20 feet. All of the maintenance workers had, and were utilizing, the appropriate clothing, safety equipment and fall protection to safely conduct the maintenance at the elevations they were working. Multiple diagonal members had been removed prior to replacing them which may have contributed to the Tower 1 collapse. Two maintenance workers were killed during this collapse and two were injured. All of the maintenance workers were still attached to the tower by their personal fall arrest systems after the collapse. The two injured maintenance workers remained conscious after the collapse.

\section{Equipment and Personnel}

Company 13 was initially dispatched for the initial cell phone tower collapse and responded with Brush Truck 13, staffed by a chief, deputy chief, and a fire fighter. Additionally, one county ambulance (A612) from the county Emergency Medical Services agency (EMS Company 61), staffed with a county emergency services lieutenant and 2 paramedics was dispatched. A second ambulance (A631), staffed with a county emergency services captain and an emergency medical technician (EMT) also responded. The assistant chief for the county emergency services agency (and also a county medical examiner) was notified at the time of the initial dispatch and he immediately responded to the scene. The dispatcher initially told the responding units they were responding to a reported structure collapse. Once on-scene, the Company 13 Chief radioed dispatch and confirmed Company 13 was onscene with confirmed entrapments. The Company 13 Chief requested heavy rescue units for extrication. All additional units that responded during the incident were dispatched on requests of officers after their arrival on the incident scene.

\section{Timeline}

- 1139 Hours

911 center receives call of cell phone tower collapse with possibility of 4 entrapments.

- 1140 Hours

Dispatch one fire company (Company 13) and one ambulance (EMS Co 61) to a structural collapse.

- 1141 Hours

Ambulance 612 (EMS lieutenant and 2 paramedics) from EMS Co 61 enroute.

- 1142 Hours

Dispatch added two fire companies as requested by Company 13 Chief.

Company 7

Company 12

Company 12 calls central dispatch and requests that a heavy rescue be dispatched to location

- 1143 Hours

Dispatch reports that it was a cell tower that collapsed and not a structural collapse. 


\section{Volunteer Fire Fighter Killed Rescuing Injured Construction Worker When Struck by Collapsing Cell Phone Tower - West Virginia}

Squad 7 (SQ7 - ambulance with 3 fire fighters onboard including the victim) from Company 7 enroute.

- 1144 Hours

Assistant Chief, county EMS enroute.

- 1145 Hours

Brush Truck 13 from Company 13 enroute with Chief, assistant chief and fire fighter on board.

- 1146 Hours

Rescue 124 from Company 12 enroute (2 fire fighters).

Brush Truck 76 from Company 7 enroute (captain).

- 1149 Hours

Brush Truck 13 on scene - drives to top of hill to cell tower site.

Brush Truck 76 on scene with Squad 7 staged at bottom of hill due to road conditions.

- 1150 Hours - 1151 Hours

Company 13 reports tower collapse on building with entrapment.

Ambulance A612 on scene - bottom of hill

Ambulance A631 on scene - bottom of hill

State Department of Natural Resources Officer on scene

Assistant Chief county EMS on scene

- 1152 Hours (approximate)

Brush Truck 76 (captain, 3 fire fighters, and A631 crew) drive to top of hill

Ambulance A612 crew staged at bottom of hill

Company 13 Chief requested electric company be notified.

State Department of Natural Resources Officer drives to top of hill

Assistant Chief county EMS drives to top of hill

- 1158 Hours

Company 7 captain requests more units to respond. Heavy rescue, Squad 51 dispatched

- 1158 Hours (approximate)

Tower 2 collapsed, striking fire fighter

\section{Personal Protective Equipment}

The deceased fire fighter and members of his department, Company 7, had on the full ensemble of structural fire fighting turnout gear and helmet.

The IC and deputy chief from Company 13 were wearing jeans and yellow hi-visibility jackets. The Company 13 fire fighter had on the full ensemble of structural firefighting equipment. 


\section{Volunteer Fire Fighter Killed Rescuing Injured Construction Worker When Struck by Collapsing Cell Phone Tower - West Virginia}

\section{Weather}

The weather was clear with an approximate temperature of 35 degrees Fahrenheit (F) when the incident occurred. Portions of the ground were covered in snow. The recorded high temperature for the day was 57 degrees $\mathrm{F}$ and the low temperature was 26 degrees $\mathrm{F}$. $^{1}$ Winds were reported to be calm and the weather was not considered to be a factor.

\section{Investigation}

On February 1, 2014, at approximately 1139 hours, central dispatch received a call reporting the collapse of a cell phone tower with entrapments and dispatched volunteer fire department Company 13 and county ambulance Company 61 at approximately 1140 hours. The chief, deputy chief and a fire fighter of the first due Company 13, arrived on the scene at approximately 1149 hours in Brush Truck 13. Access to the site was via a steeply inclined wet and muddy dirt road. The site was located on the top of a tree-covered hill. There were two cell phone towers on the site. Four workers had been conducting maintenance operations on the larger 343-foot Tower 1 when it collapsed. Tower 2 had partially collapsed leaving approximately 180 feet still standing supported by only one guy-wire.

The foreman of the maintenance crew was on the site. He informed the first due chief, who was the initial Incident Commander (IC), that two of the maintenance workers were killed by the collapse and still attached to the collapsed tower. One injured worker was still attached to the tower via his fall arrest system and one injured worker had already removed himself from the tower but was unable to walk due to leg injuries. He also told the IC that the power was still on, that there were wires everywhere, and that the second, smaller tower was not stable.

The IC entered the collapse zone to assess the condition of the two injured workers and to determine what equipment was needed to remove the workers from the tower. The IC radioed dispatch to confirm she was on the scene with reported entrapments. The IC requested heavy rescue units for extrication. The IC relayed information over the radio to the responding companies for staffing and possible equipment needed.

The second due volunteer department, Company 7 (including the Victim), arrived at the bottom of the hill at approximately 1149 hours, just behind Company 13. A captain from Company 7 arrived via a four-wheel drive brush truck (T76) while the fire fighter and two other Company 7 members responded in an ambulance, Squad 7 (SQ7). The county ambulance squad also arrived at approximately the same time in ambulance A612 staffed with an EMS lieutenant and two paramedics. Shortly after that, ambulance Squad 631 (A631) arrived with the EMS captain and his driver who, was an EMT. Due to the condition of the access road, the Company 7 fire fighters parked SQ7 at the bottom of the hill. They rode in T76 to the top of the hill which was approximately 600 yards up the access road. The EMS captain and his driver parked A631 and also rode in T76 to the top of the hill. Ambulance A612 staged at the bottom of the hill. The assistant chief of operations for the county EMS arrived at the bottom of the hill along with an officer from the state Department of Natural Resources. Both drove their 4-wheel drive vehicles up to the incident scene and parked behind T76 about 100 feet away from the tower site (Photo 2). 


\section{Volunteer Fire Fighter Killed Rescuing Injured Construction Worker When Struck by Collapsing Cell Phone Tower - West Virginia}

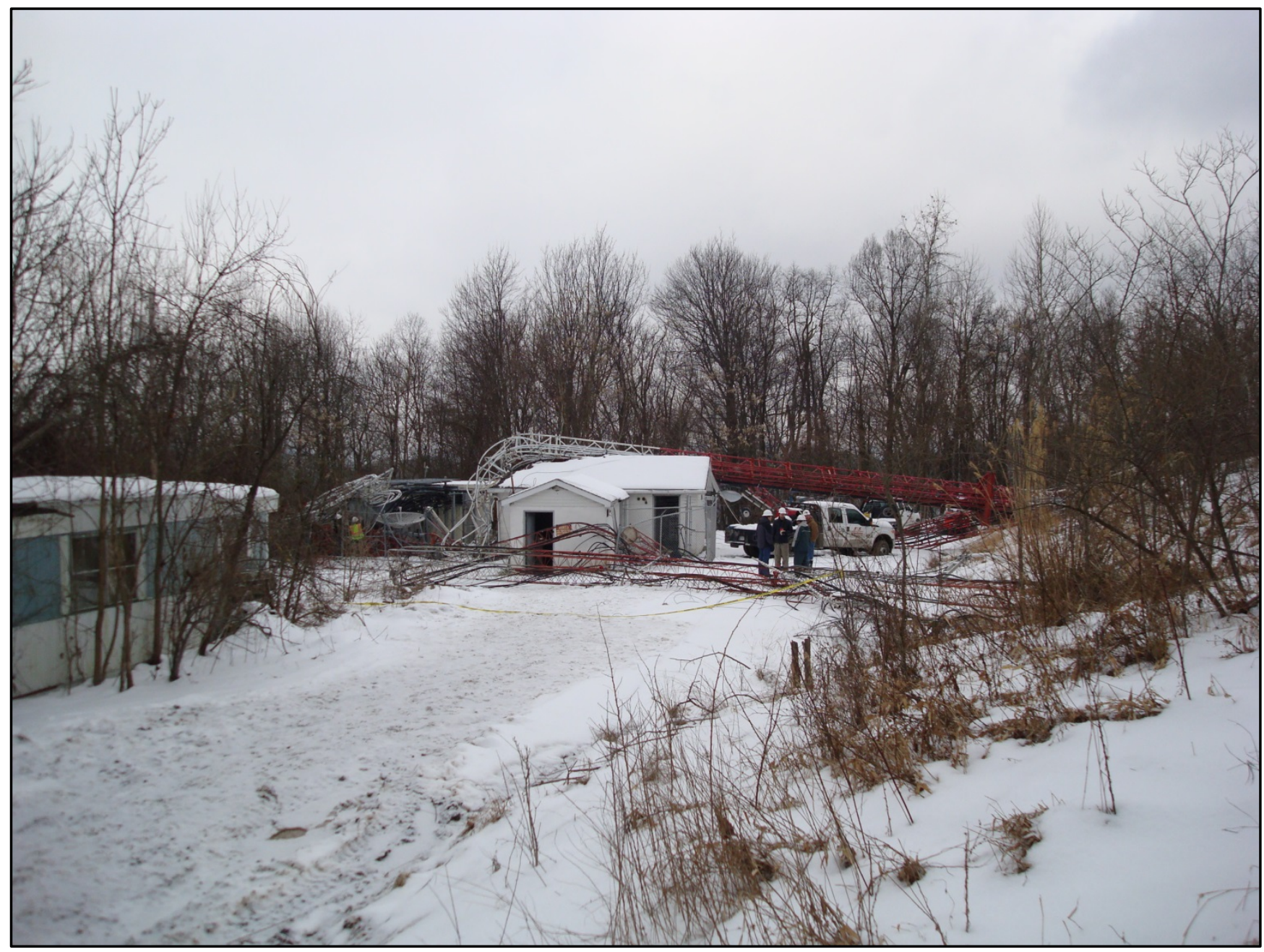

Photo 2. Area of road where the IC and responding units parked. (Photo NIOSH)

The Company 7 fire fighters and the EMS captain and his driver exited T76 on the left (driver's side). The Company 7 captain exited the passenger side of the truck and began looking for the IC. He noticed only one fire fighter in turnout gear. He approached the tower maintenance foreman and a gentleman in a yellow hi-visibility jacket who was off to the right side of T76. The foreman told the captain that the site was unsafe with live electrical hazards and the smaller tower was unstable. The Company 7 captain recognized the gentlemen in the yellow jacket as the Company 13 deputy chief and then scanned the site and saw the IC wearing a matching jacket inside the collapse zone. He notified central dispatch over the radio that he was taking command. He then had a brief discussion with the foreman and the DNR Officer about stabilizing Tower 2 and setting up a perimeter. 


\section{Volunteer Fire Fighter Killed Rescuing Injured Construction Worker When Struck by Collapsing Cell Phone Tower - West Virginia}

During this time, the Company 7 fire fighters (including the Victim) had exited T76 and were on the driver's side donning and securing gear. They did not hear their captain or any of the discussion he had with the foreman. At this time, the Company13 chief, who was near the collapsed Tower 1 with her fire fighter, continued attempting to move one of the injured maintenance workers. She yelled to the Company 7 fire fighters to provide her assistance immediately. They responded to the Company 13 chief's request and entered into the collapse zone to remove the injured worker who had previously freed himself from the wreckage. They had begun dragging the injured maintenance worker to safety when the EMS assistant chief of operations heard a noise and then saw Tower 2 begin to collapse. He yelled to the fire fighters dragging the injured worker to run. As the fire fighters were escaping, the tower collapsed to the ground (see Photo 3), striking one of the Company 7 fire fighters (the Victim) on the head, breaking his helmet. The tower collapse barely missed the injured maintenance worker and the other 3 fire fighters. The fire fighters on the scene immediately provided assistance and the downed fire fighter was taken off of the hill to an awaiting ambulance. He was transported to a local hospital where he was pronounced dead.

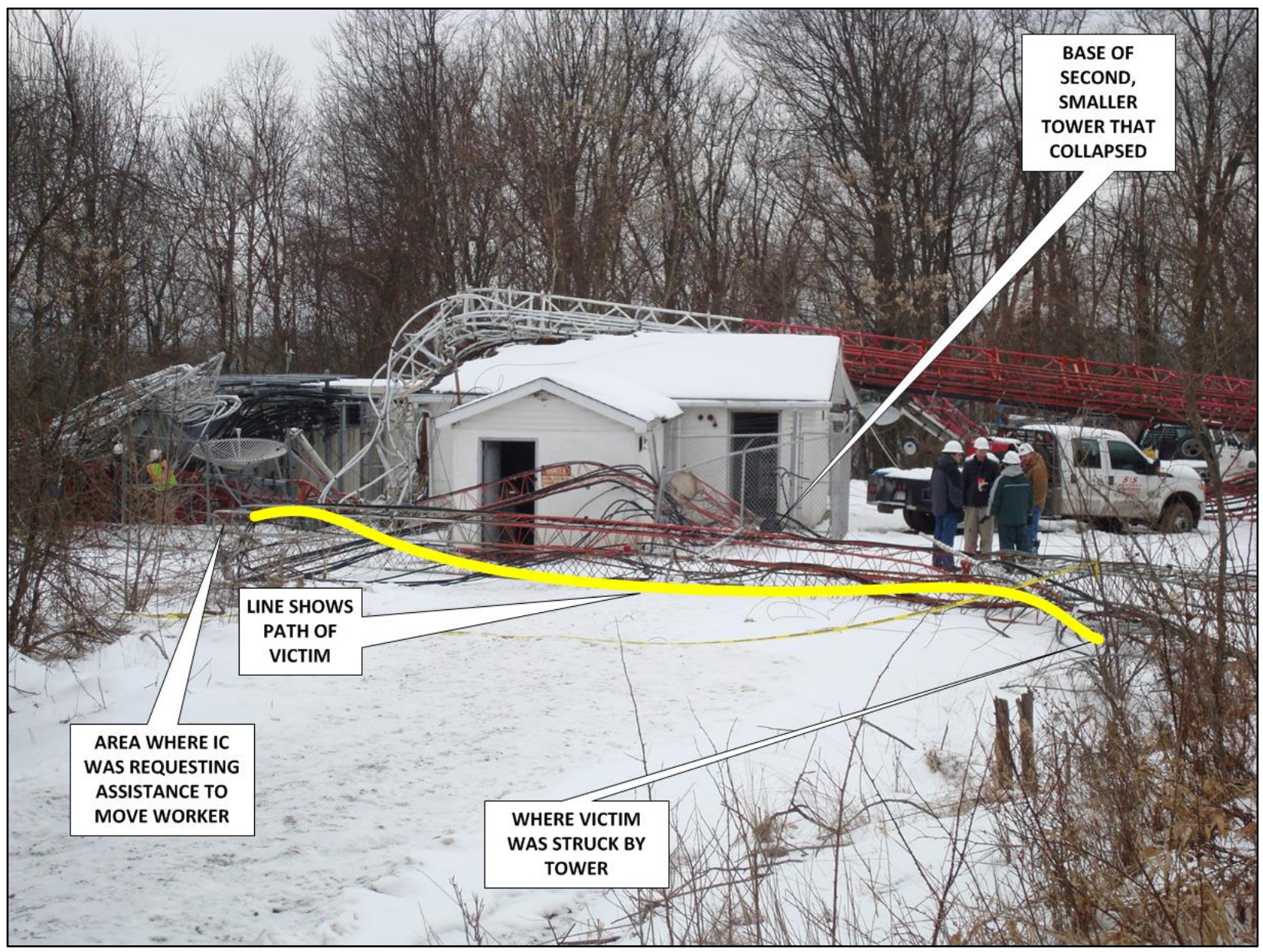

Photo 3. Locations of operations inside danger zone. (Photo NIOSH) 


\section{Volunteer Fire Fighter Killed Rescuing Injured Construction Worker When Struck by Collapsing Cell Phone Tower - West Virginia}

\section{Contributing Factors}

Occupational injuries and fatalities are often the result of one or more contributing factors or key events in a larger sequence of events that ultimately result in the injury or fatality. NIOSH investigators identified the following items as key contributing factors in this incident that ultimately led to the fatalities:

- Sequential collapses of two cell phone towers

- Ineffective Incident Command

- Lack of Situational Awareness

- Lack of training for the specific type of incident response

- Lack of an Incident Safety Officer.

\section{Cause of Death}

According to the death certificate, the medical examiner listed the fire fighter's death as blunt trauma.

\section{Recommendations}

Recommendation \#1: Fire departments should develop, implement and enforce an occupational safety and health program in accordance with NFPA 1500 Standard for a Fire Department Occupational Safety and Health Program.

Discussion: Implementation of a strong fire department occupational safety and health program following written procedures and policies such as those outlined by NFPA 1500, Standard for a Fire Department Occupational Safety and Health Program ${ }^{2}$ can foster and improve the overall safety climate of a fire department, as well as improve specific safety and health areas, such as respiratory protection, risk management, training and competency in fire ground operations, tactics, and equipment and apparatus use. Standard operating procedures (SOPs) are standard methods or rules in which an organization or a fire department operates to carry out a routine function.

In this incident, the incident commander's department was the first due company and did not have any SOPs for the NIOSH investigators to review. The second department to respond, to which the deceased fire fighter belonged, and was providing mutual aid at the incident, had a full array of SOPs covering the risks associated with fire fighting and heavy rescue (motor vehicle crash) operations.

Operational procedures should be standardized and clearly written, and training provided to each department member to ensure they understand and are familiar with the SOPs. This will establish accountability and increase command and control effectiveness. ${ }^{3}$ The benefits of having clear, concise, and practiced SOPs are numerous. For example, they can become a training outline and a tool to guide fire department members. Above all, fully implemented training on SOPs can improve departmental safety. ${ }^{4}$ 


\section{Volunteer Fire Fighter Killed Rescuing Injured Construction Worker When Struck by Collapsing Cell Phone Tower - West Virginia}

Recommendation \#2: Fire departments should ensure that the incident commander conducts an initial size-up and risk assessment of the incident scene before beginning operations, establishes a stationary command post, maintains the role of director of the incident scene and does not become involved in operations.

Discussion: According to NFPA 1561 Standard on Emergency Services Incident Management System, §5.3.1, "the incident commander shall have overall authority for management of the incident." $\underline{5}$

Among the most important duties of the first officer on the scene is conducting an initial size-up of the incident. This information lays the foundation for the entire operation. Whenever possible, a complete 360-degree size-up of the complete incident scene should be conducted by physically walking or driving around the incident site. It determines the number of fire fighters and the amount of apparatus and equipment needed to control the incident. A proper size-up begins from the moment the alarm is received and it continues until the incident is under control. The size-up should also include assessments of risk versus gain during incident operations. $\stackrel{3}{6} \underline{6-11}$

In addition to conducting an initial size-up, the incident commander must establish and maintain a command post outside of the danger area from which to assign companies and delegate functions, and continually evaluate the risk versus gain of fire ground operations. In establishing a command post, the incident commander should ensure the following (NFPA 1561, §5.3.7.1):

- The command post is designated to establish presence and visibility. In most cases, this would be located in or limited to the Incident Commander's vehicle. Part of the 360-degree size-up is to determine the best location for the command post.

- The command post includes radio capability to monitor and communicate with assigned tactical operations, command, and designated emergency traffic channels for that incident.

- The location of the command post is communicated to the communications center.

- The incident commander, or designee, is present at the command post at all times.

- The command post is located in the incident cold zone.

A delay in establishing an effective command post may result in confusion in assignments of personnel and apparatus coordination which may contribute to unsafe operations. The involvement of the IC in operations hampers the collection and communication of essential information in continually evaluating the situation and maintaining accountability. ${ }^{8}$ To effectively coordinate and direct operations on the scene, it is essential that the IC does not become involved in operational efforts.

In this incident, a stationary command post outside of the danger area was never established. In addition, separate and uncoordinated activities were taking place on the incident scene. While it is a commonly accepted practice within the fire service for the first-arriving company officer to become directly involved and engage the incident (fast attack mode), procedures need to be in place so that there is a quick and efficient transfer of command as additional resources arrive. In this incident, the initial incident commander (Company 13 Chief) quickly became involved in operational efforts to remove one of the injured construction workers (fast attack mode). This may have contributed to a failure to size-up the overall incident scene, properly evaluate risk versus gain, communicate and 


\section{Volunteer Fire Fighter Killed Rescuing Injured Construction Worker When Struck by Collapsing Cell Phone Tower - West Virginia}

evaluate operations, and establish and maintain a danger/collapse zone. The collapsed Tower 1 was still energized and the potential for a complete collapse of Tower 2 may have gone unrecognized as rescuers focused on moving the injured maintenance workers, even though the site foreman told the incident commander that Tower 2 was unstable. When the Company 7 captain arrived on-scene, he radioed dispatch that he was taking incident command but there was no formal exchange with the initial incident commander as she was engaged in the rescue efforts. The Company 7 captain was discussing the scene situation with the site foreman and others as part of his size-up process when the second tower collapsed. When incident commanders get involved in operational tasks, they may focus on these specific task(s), which further restricts their ability to focus on the "big picture" and effectively manage the incident. The collection and processing of the initial incident information is likely to be more practiced for structure fires and hazmat events than a technical rescue event due to the basic unfamiliarity with the risks associated with technical rescue events, as they typically occur less frequently. In this event, the responders were clearly under stress and a perceived time constraint to reach and rescue the injured maintenance workers.

\section{Recommendation \#3: Fire departments should ensure that fire fighters are trained in situational awareness, personal safety, and accountability.}

Discussion: All fire fighters operating at an incident should maintain situational awareness and conduct a continuous risk assessment throughout the incident, reporting unsafe or changing conditions to the Incident Commander. Fire fighters need to understand the importance of situational awareness, personal safety, and personal accountability at the incident scene. While at the incident scene, dangers and hazards can change as the incident becomes larger and the event duration increases. The structural integrity of damaged structures can change significantly and endanger areas of the incident scene not previously at risk during earlier stages of the event.

Essentials of Fire Fighting and Fire Department Operations ${ }^{3}$ defines situational awareness as an awareness of the immediate surroundings. On the fire ground, every fire fighter should be trained to be constantly alert for changing and unsafe conditions. Even though a safety officer may have been designated for the incident, all personnel are obligated to remain alert to their immediate surroundings. They must maintain their situational awareness and be alert for unsafe conditions. This applies not only to the conditions found within a burning structure, but to the exterior fire ground as well. ${ }^{4}$

One of the most critical aspects of coordination between crews is maintaining situational awareness. The opposite of situational awareness is tunnel vision where the fire fighters become so focused on fire-fighting or other operational assignments that they fail to sense changes in their environment. Fire fighters can maintain their situational awareness by looking up, down, and around themselves as well as listening for new or unusual sounds and feeling vibrations or movement. Fire fighters and officers should communicate any changes in their environment to other members as well as to the Incident Commander.

Technical rescue incidents are high risk and low frequency events making them particularly hazardous to responders. When responding to an incident on any type of technical rescue or collapse, fire fighters 


\section{Volunteer Fire Fighter Killed Rescuing Injured Construction Worker When Struck by Collapsing Cell Phone Tower - West Virginia}

and other first responders must ensure their personal safety as well as the safety of others, including the individuals they are trying to assist and help. Complacency and lack of situational awareness are issues that all responders must avoid when dealing with technical rescue incidents. Safety of the emergency responders, care of the injured, protection of the public and environment, should all be the priority concerns of the Incident Commander.

To ensure that first responders maintain situational awareness, they should understand the strategy of the Incident Action Plan (IAP) which should be developed and communicated from the Incident Commander at the beginning of the incident and maintained throughout the duration of the incident. This ensures effective strategic, tactical, and task level management, so that all tasks being conducted move toward a successful outcome. At technical rescue incidents, maintaining situational awareness is essential due to the potential for something to go wrong very quickly. Each first responder is responsible for their safety plus the personnel they are working with. Maintaining situational awareness protects against complacency and tunnel vision. The incident scene creates a significant risk to fire fighters and it is the responsibility of the Incident Commander and command organization officers to minimize fire fighter exposure to unsafe conditions and stop unsafe practices. $\underline{12}$

In this incident, command was never established nor was any type of Incident Action Plan developed and communicated to arriving personnel. The IC was inside the collapse zone attempting to move an injured worker when additional crews arrived on the scene. The IC then requested assistance inside the collapse zone from responding crews. A potential collapse hazard from Tower 2 and the possible electrical hazards from the energized Tower 1 were present inside the collapse zone, but were not communicated to the fire fighters from Company 7.

\section{Recommendation \#4: Fire departments should develop pre-incident plans for deployment to technical rescue incidents and conduct a risk benefit analysis for the deployment.}

Discussion: The communication system, or central dispatch center, is used for receiving notification of emergencies, alerting personnel and equipment, coordinating the activities of the units engaged in emergency incidents, and providing nonemergency communications for the coordinating fire departments. The dispatch system must be able to identify the type and number of units due to respond to the type of incident in advance based on risk criteria and unit capabilities. $\frac{13}{}$ The central dispatch center in the county where this incident occurred receives the information on deployment to specific incidents from the county fire chief's association.

It is important that each fire department, as determined by the authority having jurisdiction, develop pre-incident plans regarding deployment to technical rescue incidents and conduct a risk benefit analysis of the deployment to protect the safety of all responders. Pre-planned responses should be based upon a critical task analysis of the potential incident to help ensure that an appropriate response (both proper staff and proper equipment) is initiated. Pre-incident plans should be developed based upon the incident specific hazards that can be anticipated. $\underline{5}$ Some fire departments may not have the resources to support a technical rescue team..$^{4}$ Many communities rely on mutual aid or a combination of jurisdictional resources to provide technical rescue capabilities for complex incidents such as 


\section{Volunteer Fire Fighter Killed Rescuing Injured Construction Worker When Struck by Collapsing Cell Phone Tower - West Virginia}

structural collapse, hazardous materials response, trench or confined space rescues. In this incident, fire departments within the county did not anticipate the hazards associated with responding to an incident involving a collapsed cell phone tower with another, partially-collapsed tower still standing. NFPA 1561, Section 4.4.5 states the emergency services organization (ESO) shall prepare and adopt written plans based on the incident management system that addresses the requirements of the different types of incidents that can be anticipated.

A program that measures the risk versus benefit of a particular emergency operation is crucial to the safety of all emergency responders. A risk-benefit analysis must be performed on two levels: executive and on-scene. At the executive or strategic level, municipal and fire department leaders should identify their mission capabilities or plan for expanding their current capabilities through longterm funding, training, and continued support. Emergency incident risk-benefit analysis is performed on the scene, by the first arriving responders, and is continued throughout the incident by the command structure. For the occurrence of more infrequent incidents requiring technical rescuer professional level operations, preplanning and strategic level risk-benefit analysis can identify the level of response that can be safely performed and alternatives such as mutual aid or multi-jurisdictional, multi-agency capabilities that can be utilized. $\stackrel{14}{ }$ NFPA 1250 Recommended Practice in Fire and Emergency Services Organization Risk Management, 2010 Edition ${ }^{15}$ provides recommendations to identify risk and develop risk analysis for fire and emergency services organizations. A risk assessment can identify existing and potential risks through an evaluation of operational activities, exposure situations and prior loss experience. A risk analysis should employ techniques applicable to the type of loss exposure or the hazard involved.

In this incident, central dispatch deployed what was recommended to them by the county fire chief's association. The request for additional units or an upgrade is at the request of the incident commander. A "Best Practice" would be to have pre-planned responses for technical rescue incidents, including how to deal with incidents that involve collapse and entrapment. A full response to a technical rescue incident should provide the necessary personnel and equipment to carry out the operation in a safe and effective manner. A dedicated safety officer as required by NFPA 1500, Chapter 8.1.6 and 8.3.5 and specialized equipment such as a hand held voltage detectors, are examples of the resources that would be necessary to ensure responder safety on a similar incident. $\frac{2,16}{2}$

NFPA 1670, Standard on Operations and Training for Technical Search and Rescue Incidents, requires that a hazard identification and risk assessment of the response area be conducted in order to determine what hazards exist that could require technical search and rescue operations. This includes identifying the external resources for when situations arise that are beyond the primary response organization's capabilities. ${ }^{17}$ Chapter 16 of NFPA 1670 defines the specific requirements that organizations that provide varying degrees of response to emergencies involving guyed, selfsupporting, monopoles and nonstandard tower structures must meet. NFPA 1670, Section 16.1.5 states that the authority having jurisdiction (AHJ), as part of its hazard identification and risk assessment, shall identify all locations and situations in the jurisdiction that meet the definition of "towers" and shall make reasonable effort to pre-plan with the tower owner, manager, operator or other AHJ for potential tower emergencies, including the associated hazards to emergency responders such as structural integrity, radio frequency (RF) radiation, electrical shock hazards, and others. $\frac{16}{}$ 


\section{Volunteer Fire Fighter Killed Rescuing Injured Construction Worker When Struck by Collapsing Cell Phone Tower - West Virginia}

\section{Recommendation \#5: Fire departments should ensure that a separate Incident Safety Officer, independent from the Incident Commander, is appointed at technical rescue incidents.}

Discussion: David Dodson, author of the book Fire Department Incident Safety Officer, states that firefighters" "can-do" attitude compels the fire fighter to action whether they are adequately trained for the specific situation or not. ${ }^{4}$ Resourcefulness, inventiveness, willingness, and compassion drive fire fighters to find a solution. From the Incident Safety Officer's perspective, these same attributes lead directly to fire fighter injuries and deaths. Firefighting history is full of examples of willing fire fighters who got caught up in a situation that soon overwhelmed them, resulting in tragedy. ${ }^{4}$ Chapter 16 of this book describes the role of the Incident Safety Officer at technical rescue incidents.

According to NFPA 1561 Standard on Emergency Services Incident Management System, 2014 Edition, paragraph 5.3, "The Incident Commander shall have overall authority for management of the incident (5.3.1) and the Incident Commander shall ensure that adequate safety measures are in place (5.3.2).” This shall include overall responsibility for the safety and health of all personnel and for other persons operating within the incident management system. While the Incident Commander (IC) is in overall command at the scene, certain functions must be delegated to ensure adequate scene management is accomplished..$^{-}$According to NFPA 1500 Standard on Fire Department Occupational Safety and Health Program, 2013 Edition, "as incidents escalate in size and complexity, the Incident Commander shall divide the incident into tactical-level management units and assign an incident safety officer (ISO) to assess the incident scene for hazards or potential hazards (8.1.6)." "․ㅡㄹ These standards indicate that the IC is in overall command at the scene, but acknowledge that oversight of all operations is difficult. On-scene fire fighter health and safety is best preserved by delegating the function of safety and health oversight to the ISO. Additionally, the IC relies upon fire fighters and the ISO to relay feedback on fireground conditions in order to make timely, informed decisions regarding risk versus gain and offensive versus defensive operations. The safety of all personnel on the fireground is directly impacted by clear, concise, and timely communications among mutual aid fire departments, division/group supervisors, the ISO, and IC.

Chapter 6 of NFPA 1521, Standard for Fire Department Safety Officer, defines the role of the ISO at an incident scene and identifies duties such as: recon of the fireground and reporting pertinent information back to the Incident Commander; ensuring the department's accountability system is in place and operational; monitoring radio transmissions and identifying barriers to effective communications; and ensuring established safety zones, collapse zones, hot zones, and other designated hazard areas are communicated to all members on scene. ${ }^{16}$ Larger fire departments may assign one or more full-time staff officers as safety officers who respond to working fires. In smaller departments, every officer should be prepared to function as the ISO when assigned by the IC. The presence of a safety officer does not diminish the responsibility of individual fire fighters, fire officers, and the incident commander for safety. The ISO adds a higher level of attention and expertise to help the fire fighters and fire officers. The ISO must have particular expertise in analyzing safety hazards and must know the particular uses and limitations of protective equipment. 


\section{Volunteer Fire Fighter Killed Rescuing Injured Construction Worker When Struck by Collapsing Cell Phone Tower - West Virginia}

This incident involved a technical rescue situation involving injured and deceased workers trapped within the wreckage of a collapsed cell phone tower. The site foreman advised the responding fire fighters that the remaining tower was unstable and the electrical power was still on. A designated safety officer could have assisted at this incident with continual size-up, accountability, and timely communications regarding the safety and stability of the remaining tower.

\section{Recommendation \#6: Fire departments, especially volunteer departments, should consider limiting} their special operations functions to those that they are properly trained and equipped for.

Discussion: NFPA 1720 Standard for the Organization and Deployment of Fire Suppression Operations, Emergency Medical Operations, and Special Operations to the Public by Volunteer Fire Departments $^{\underline{13}}$ contains the minimum requirements relating to the organization and deployment of fire suppression operations, emergency medical operations, and special operations (such as technical rescue) to the public by volunteer and combination fire departments. The purpose of this standard is to specify the minimum criteria addressing the effectiveness and efficiency of the volunteer and combination public fire suppression operations, emergency medical service, and special operations delivery in protecting the citizens of the jurisdiction. NFPA 1720, Section 4.10 addresses special operations. Section 4.10.4 states "the fire department shall limit its operations to only those specific special operations functions for which its personnel are trained and are properly equipped." Additionally, Section 4.10.7 states "the fire department shall have the capacity to implement a RIC (rapid intervention crew) during all special operations incidents that would subject fire fighters to immediate danger of injury, or in the event of equipment failure or other sudden events, as required by NFPA 1500.”

In this event, the first due volunteer fire department was initially dispatched for the report of a structural collapse and responded with three department members. Once on-scene, the initial incident commander radioed dispatch to confirm the cell phone tower collapse with construction workers trapped. Due to the lack of training records for the first-due company and lack of individual training records for the initial incident commander and fire fighter, their capacities to participate in special operations could not be determined. As additional companies arrived on-scene, there was no indication that a rapid intervention crew was established as fire fighters engaged in the special operation to rescue the construction workers.

\section{References}

1. Weather Underground [2014]. Weather history for the immediate area on February 1, 2014. http://www.wunderground.com/history/airport/KCKB/2014/2/1/DailyHistory.html?req_city=N A\&req_state=NA\&req_statename=NA . Date accessed: August 27, 2014.

2. NFPA [2013]. NFPA 1500: Standard on Fire Department Occupational Safety and Health Program. 2013 Edition. Quincy, MA: National Fire Protection Association. 


\section{Volunteer Fire Fighter Killed Rescuing Injured Construction Worker When Struck by Collapsing Cell Phone Tower - West Virginia}

3. IFSTA [2008]. Essentials of fire fighting, 5th ed. Oklahoma State University. Stillwater, OK: Fire Protection Publications, International Fire Service Training Association.

4. Dodson D [2007]. Fire Department Incident Safety Officer. 2nd Edition. New York: Thomson Delmar Learning.

5. NFPA [2014]. NFPA 1561 Standard on Emergency Services Incident Management System, 2014 Edition. Quincy, MA: National Fire Protection Association.

6. Dunn V [1992]. Safety and Survival on the Fireground. Saddle Brook NJ: Fire Engineering Books and Videos.

7. Dunn V [2000]. Command and Control of Fires and Emergencies. Saddle Brook NJ: Fire Engineering Book and Videos.

8. Brunacini AV [1985]. Fire command. Quincy, MA: National Fire Protection Association.

9. Dunn V [1998]. Risk management and lightweight truss construction. New York: WNYF, Official training publication of the New York City Fire Department, 1st issue.

10. NIOSH [1999]. NIOSH Alert: Request for assistance in preventing injuries and deaths of fire fighters due to structural collapse. Cincinnati, OH: U.S. Department of Health and Human Services, Public Health Service, Centers for Disease Control and Prevention, National Institute for Occupational Safety and Health. (NIOSH) Publication No. 99-146.

11. NIOSH [2014]. NIOSH workplace solution: preventing deaths and injuries to fire fighters by establishing collapse zones at structural fires. Cincinnati, OH: U.S. Department of Health and Human Services, Centers for Disease Control and Prevention, National Institute for Occupational Safety and Health. (NIOSH) Publication No. 2014-120.

12. IAFC [2012]. Rules of engagement for structural firefighting. Fairfax VA: International Association of Fire Chiefs, Safety, Health and Survival Section http://websites.firecompanies.com/iafcsafety/files/2013/10/Rules_of_Engagement_short_v10_2 .12.pdf.

13. NFPA [2014]. NFPA 1720, Standard for the Organization and Deployment of Fire Suppression Operations, Emergency Medical Operations, and Special Operations to the Public by Volunteer Fire Departments, 2014 Edition. Quincy, MA: National Fire Protection Association

14. NIOSH [2008]. Career fire fighter dies while diving for a civilian drowning victim - Rhode Island Morgantown, WV: U.S. Department of Health and Human Services, Centers for Disease Control and Prevention, National Institute for Occupational Safety and Health, Fatality Assessment and Control Evaluation (FACE) Report F2008-32 


\section{Volunteer Fire Fighter Killed Rescuing Injured Construction Worker When Struck by Collapsing Cell Phone Tower - West Virginia}

http://www.cdc.gov/niosh/fire/reports/face200832.html . Date accessed: August 27, 2014.

15. NFPA [2010]. NFPA 1250: Recommended Practice in Fire and Emergency Services Organization Risk Management. Quincy, MA: National Fire Protection Association.

16. NFPA [2015]. NFPA 1521: Standard for Fire Department Safety Officer, 2015 Edition. Quincy, MA: National Fire Protection Association.

17. NFPA [2014]. NFPA 1670: Standard on Operations and Training for Technical Search and Rescue Incidents, 2014 Edition. Quincy, MA: National Fire Protection Association.

\section{Investigator Information}

This incident was investigated by Jay L. Tarley, Safety and Occupational Health Specialist, Matt Bowyer, General Engineer, and Tim Merinar, Safety Engineer and Project Officer with the Fire Fighter Fatality Investigation and Prevention Program, Surveillance and Field Investigations Branch, Division of Safety Research, NIOSH located in Morgantown, WV. Expert technical reviews were provided by Chief Joseph V. Maruca, West Barnstable Massachusetts Fire Department and Chief Ulysses Seal, Bloomington Minnesota Fire Department. A technical review was also provided by the National Fire Protection Association, Public Fire Protection Division.

\section{Additional Information}

OSHA News Release: 14-198-NAT. No more falling workers. OSHA focuses on protecting cell tower employees after increase in worksite fatalities. https://www.osha.gov/pls/oshaweb/owadisp.show_document?p_table=NEWS_RELEASES\&p_id=255 $\underline{93}$

\section{Disclaimer}

Mention of any company or product does not constitute endorsement by the National Institute for Occupational Safety and Health (NIOSH). In addition, citations to Web sites external to NIOSH do not constitute NIOSH endorsement of the sponsoring organizations or their programs or products. Furthermore, NIOSH is not responsible for the content of these Web sites. 